\title{
CONSUMPTION AND OFFER OF ORGANIC FOOD ON THE SLOVAK MARKET
}

\author{
Kristína Predanocyová, Peter Šedík ${ }^{1}$ Lubica Kubicová ${ }^{1}$, Elena Horská ${ }^{1}$ \\ ${ }^{1}$ Department of Marketing and Trade, Faculty of Economics and Management, Slovak University of Agriculture \\ inNitra, Trieda A. Hlinku 2, 94976 Nitra, Slovak Republic
}

To cite this article: PREDANOCYOVÁ KRISTÍNA, ŠEDÍK PETER, KUBICOVÁ LUUBICA, HORSKÁ ELENA. 2018. Consumption and Offer of Organic Food on the Slovak Market. Acta Universitatis Agriculturae et Silviculturae Mendelianae Brunensis, 66(5): 1315-1323.

To link to this article: https://doi.org/10.11118/actaun201866051315

\begin{abstract}
The growing interest of consumers in the products of organic farming is currently considered as a trend on the food market. The aim of the submitted paper is to characterize organic farming, the production, the offer of organic food in Slovak retails and the position of consumers on the organic food market in Slovakia. For evaluating the situation of organic farming in Slovakia, secondary data from the database of Research Institute of Agricultural and Food Economics and Central Institute of Control and Testing in Bratislava were used. The primary data were obtained through two survey questionnaires. The aim of the first of them was to find out the offer of organic food in retail stores in Slovakia. Based on the results, we can state that most of the addressed retailers sell organic food and the most widespread are dairy products and bakery products. Nowadays, the offer of organic food is the same as the most desirable products by consumers. $40 \%$ of the surveyed Slovak retails have specially labelled products of organic farming placed among conventional foods. The second conducted questionnaire survey, which aim was to determine buying behaviour of young consumers on the Slovak market. Based on the results, it could be stated that consumers mostly purchase organic food in specialized stores, supermarkets, hypermarkets, and they mainly decide according to the quality and origin of the food.
\end{abstract}

Keywords: consumer, consumer behaviour, retail, organic farming, organic food

\section{INTRODUCTION}

Nowadays, consumers during the food selection take into consideration their lifestyle (Chrysochou, 2010), which could be considered as an increasing trendonthe food market. When making a purchase decision, they focus on health and nutritive aspects of each product category (Nagyová et al., 2012; Kretter and Kádeková, 2013; Paluchová and Benda Prokeinová, 2014). Rovný et al. (2010) emphasize that consumers should not only concentrate on the consumption of selected food categories but also to prefer variety and food diversity.
Zámková and Prokop (2013) highlight that consumers should be interested in seeking information about the country of origin and processing method with a regard to the environment. All these attributes are fulfilled in case of organic food, where consumers perceive them as healthier, safer, tastier and more ecological alternative to their conventional substitutes (Magnusson et al., 2003; Yiridoe et al., 2005; Hughner et al., 2007; Aertsens et al., 2011; Gottschalk and Leistner, 2013).

These aspects represent the main reasons of purchase which is reflected in constant increasing of its consumption (Živelová and Crhová, 2012). 
On the other hand, it is necessary to point out the barriers in consumption of organic food such as unfavourable economic situation which leads to stagnation and decrease of inhabitants' income as well as expenditures on organic food (Lehmann, 2005), followed by relative high prices (Frýdlová and Vostrá, 2011), insufficient information (Demeritt, 2002; Vácvalík, 2009) and their availability in retail stores (Kretter, 2005; Nagyová et al., 2012). As far as the consumption of organic food is increasing, it is necessary to analyse the production itself.

In conditions of the Slovak Republic, the importance of organic food is gradually increasing. The statement is based on an increasing tendency of cultivated land under organic farming and, currently, it represents a 10\% share (187 011 ha) of total cultivated land in the Slovak Republic. According to the data from Research Institute of Agricultural and Food Economics (2017) and the applied index of determination $\left(\mathrm{R}^{2}\right)$ with $59.2 \%$ confidence, it could be stated that the percentage development regarding the size of cultivated areas under organic farming in relation to total cultivated area for the next two years (2017 - 2018) will rise and reach approximately $10.2-10.3 \%$ share (Predanocyová et al., 2017).

It is assumed that the above-mentioned development reflects consumers' needs and requirements in terms of organic food, and organic farming will become more perspective and demanded industry for farmers and food processors. On 31st of January 2018, 94 processors of organic food operate

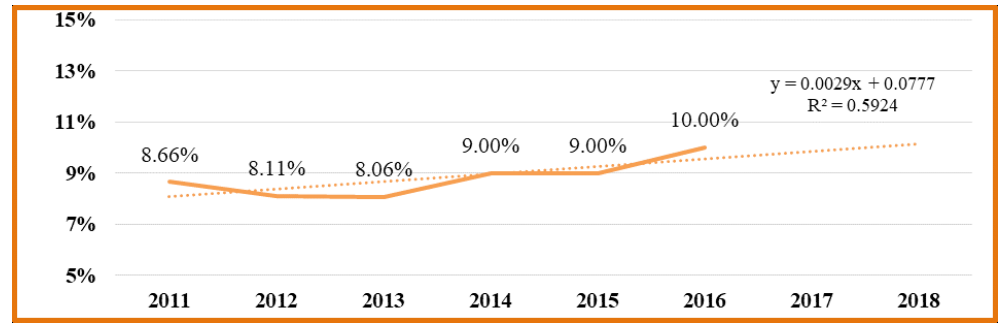

1: Percentage share of agricultural land in the system of organic farming on the total area of agricultural land Source: Predanocyová et al. (2017)

I: The most famous processors involved in the production of food from organic farming

\begin{tabular}{lc}
\hline \multicolumn{1}{c}{ Food products } & The most famous processors \\
\hline $\begin{array}{l}\text { Dairy products and eggs } \\
\text { Mill products } \\
\text { Bread and bakery products } \\
\text { Meat products }\end{array}$ & Tatranskámliekareň a. s., Kežmarok, AGRO TAMI, a. s., Nitra \\
Beverages, coffee and tea & MlynPohronskýRuskov, BIOMILA spol. s r. o., MINIT SLOVAKIA spol. s r. o. \\
Honey & BiofarmaŠuňava PD, ALFA BIO \\
Other food products & MLCarter a. s. Bratislava, Baliarneobchodu, a. s. Poprad, \\
\hline
\end{tabular}

Source: The Central Institute of Control and Testing, 2018

II: Certified food products produced in organic farming in the period 2013-2016

\begin{tabular}{lccccc}
\hline \multicolumn{1}{c}{ Food products } & M.u. & $\mathbf{2 0 1 3}$ & $\mathbf{2 0 1 4}$ & $\mathbf{2 0 1 5}$ & $\mathbf{2 0 1 6}$ \\
\hline Processed and preserved fruits and vegetables & $\mathrm{kg}$ & 2894232 & 4442840 & 534888 & 141828 \\
& $\mathrm{l}$ & 2298440 & 883315 & 413998 & 393726 \\
Dairy products and cheese & $\mathrm{l}$ & 5934700 & 5605901 & 343561 & 2111012 \\
\hline Mill products & $\mathrm{kg}$ & 1174800 & 3859400 & 861343 & 787109 \\
Bread and bakery products & $\mathrm{kg}$ & 4522800 & 13768501 & 656434 & 664817 \\
Oils and fats & $\mathrm{kg}$ & 2562030 & 30094610 & 462721 & 587476 \\
& $\mathrm{l}$ & 22000 & 7470 & 12794 & 2752 \\
Other food products & $\mathrm{kg}$ & 1437400 & 658400 & 402335 & 620111 \\
\hline Processed and preserved meat & $\mathrm{kg}$ & 4391602 & 399700 & 19236 & 2133362 \\
Prepared dishes and meals & $\mathrm{l}$ & 3150 & 2200 & 2808 & 39 \\
\hline
\end{tabular}

Source: The Central Institute of Control and Testing in Bratislava, 2017 
in the Slovak Republic. The most famous processors are shown in Tab. 1 divided according to product categories. The interesting fact occurs in terms of organic honey, which is represented by only one company-Bioapis-SK Včeliafarma.

In the context of organic production in the Slovak Republic, it is inevitable to examine the quantities of new-certified food products produced in organic farming. According to the information from the Central Institute of Control and Testing in Bratislava (see Tab. II), the quantities of new-certified organic products have an increasing tendency on Slovak market. In general, the products are divided into several product categories, such as processed or preserved fruits and vegetables, dairy products and cheese, mill products, bread and bakery products, oils and fats, processed and preserved meat, prepared dishes and meals, and other food products. In an observed period of years 2013-2016, the quantities of new-certified organic food is increasing which is reflected in an increased offer in Slovak retail stores.

The total size of the cultivated area in organic farming is continuously increasing, however, in Slovak conditions, the production of organic food is not sufficient. The demand for this product category is still rising and it is necessary to import organic products from abroad, therefore distributors are inevitable onthe market with organic food. The most frequent are retail stores, which offer organic food of various product categories to final consumers whose interest towards organic consumption is increasing (Živělová and Crhová, 2013).

\section{MATERIALS AND METHODS}

The main aim of the paper was to identify consumer behaviour of young generation towards organic food as well as to analyse the offer of organic food in Slovak retail stores. The paper objectives were based on secondary and primary data. The secondary data included information from Research Institute of Agricultural and Food Economics and Central Institute of Control and Testing in Bratislava. The primary data were based on two questionnaire survey conducted in the period of December-February 2017/2018.

The first questionnaire survey was focused on the purchasingbehaviour of the young generation up to 30 years in Slovakia, and research sample reached 663 respondents. From socio-demographic point of view, the sample comprises both males (43.0\%) and females (57.0\%) in age of 18-24 years (50.7\%) and $25-30$ years $(49.3 \%)$, living in the city $(52.9 \%)$ or in the village (47.1\%), with elementary education (1.4\%), secondary vocational education (4.4\%), secondary education (46.3\%) and higher education (48.0\%). The majority of respondents were students $(49.4 \%)$ or employed (41.3\%) with the income level of up to 400 $€(49.0 \%), 401-600 €(15.1 \%), 601-800 €(18.5 \%)$ and more than $800 €(17.4 \%)$.

The second questionnaire survey was oriented on retail stores in the Slovak Republic with the aim at organic food offer, its merchandising, origin and consumers' preferences from a managers' point of view. The survey comprised 106 retail stores with various size of selling area: up to $400 \mathrm{~m}^{2}$ (70.4\%), $400 \mathrm{~m}^{2}-2500 \mathrm{~m}^{2}(20.8 \%)$ and more than $2500 \mathrm{~m}^{2}$ (1.9\%). According to the geographical division, the majority of stores were situated in Western Slovakia including Bratislava region (70.7\%), followed by Central Slovakia (15.1\%) and Eastern Slovakia (13.2\%).

For a deeper analysis of research objectives were formulated the following hypotheses:

- Hypothesisl: there exists dependence between the purchase of organic food and respondent's gender.

- Hypothesis2: there exists dependence between the purchase of organic food and respondent's age.

- Hypothesis3: there exists dependence between the purchase of organic food and respondent's level of education

- Hypothesis 4: there exists dependence between the purchase of organic food and respondent's income

- Hypothesis 5: there exists dependence between the place of organic food purchase and respondent's place of residence.

- Hypothesis 6: there exists a difference in the price evaluation at the purchase of organic food and respondent's gender.

- Hypothesis 7: there exists dependence between the awareness of organic honey and consumer perception of conventional and organic honey

The formulated hypotheses were tested by applying the following statistical tests:

- Chi-Square Test of Independence

- Cramer's contingency coefficient

- Mann Whitney U test

- Fisher's exact test

All the above-mentioned tests have been calculated in statistical software SAS Enterprise Guide 7.1. In hypothesis testing, if the p-value is lower than significant level, in case of SAS software, it is 0.05 , the null hypothesis is rejected and the alternative hypothesis is confirmed (Košičiarováet al., 2017; Witek, 2016).

\section{RESULTS AND DISCUSSION}

The results of the survey proved, that young generation of Slovak consumers are interested in organic food. $41.0 \%$ of all respondents participated in survey purchase food which was produced in organic farming.

Regarding to this question several dependencies were examined between the selected socio-demographic variables of the respondents and the purchase of organic food. Applying the statistical tests of Chi-squared test of Independence and Fisher 's exact test, no statistically significant dependency has been proved between purchasing of organic foods and gender ( $p$-value $=0.0917)$, education 
$(p$-value $=0.9342)$ and income $(p$-value $=0.1119)$. The only dependency was confirmed in case of respondent's age $(p$-value $=0.0045)$. Based on the Cramer's V-coefficient (0.1111) it could be concluded, that the strength of dependency is weak.

Out of all surveyed respondents who purchase the organic food, $41.2 \%$ of consumers prefer supermarkets and hypermarkets, $34.2 \%$ prefer specialized stores, $11.0 \%$ purchase the organic foods directly from producer and $3.3 \%$ of consumers prefer the purchase via the Internet. Remaining $10.3 \%$ of respondents are not purchasing any organic food, yet they rather grow organic food in their own gardens. Zámková and Prokop (2014) came to the similar conclusion, that consumers purchase organic food mostly in supermarkets and hypermarkets (31.3\%), in stores specialized on healthy nutrition and organic food (16.3\%), directly from farmers and agriculture markets (5.4\%) and $17.7 \%$ of respondents grow the organic food by themselves.

By this question another dependence was examined between the location of the organic food purchase and permanent residence of the respondents. Applying the statistical test of Chi-squared test of Independence with significance level $\alpha=0.05$, the null hypothesis was rejected ( $p$-value $=0.0001$ ) and confirmed statistically important difference between the place of organic food purchase and respondents' residence. Based on the calculation of Cramer's V-coefficient (0.2920) it could be concluded that the strength of dependency is weak.

In the context of above, it could be stated that nowadays, the organic food is offered in all types of retails in the Slovak Republic, which confirm the results of our research conducted on retails. Results showed, that up to $75 \%$ of the retails offer organic food as a part of their assortment. Kalužáková (2011) conducted field research in retails and found that $76.5 \%$ of the stores also offer a range of organic food. In terms of product categories, $85 \%$ of surveyed retail stores in the Slovak Republic offer milk and dairy products produced in organic farming, such as yoghurts, fresh butter and milk or curd from the producers Rajo, Tatranskámliekareň and Agro Tami. The assortment of organic flour and

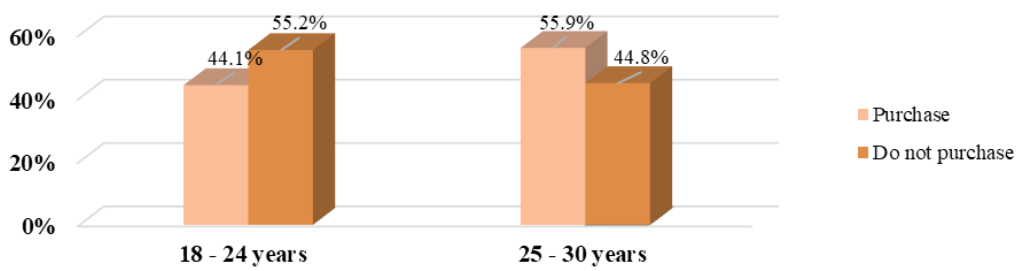

2: Purchase of organic food according to age of respondents Source: own research, 2018

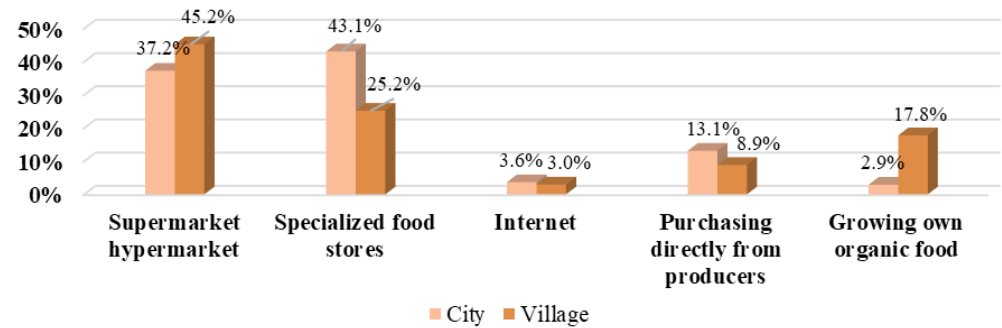

3: Place of purchase of organic food according to the permanent residence of the respondents Source: own research, 2018

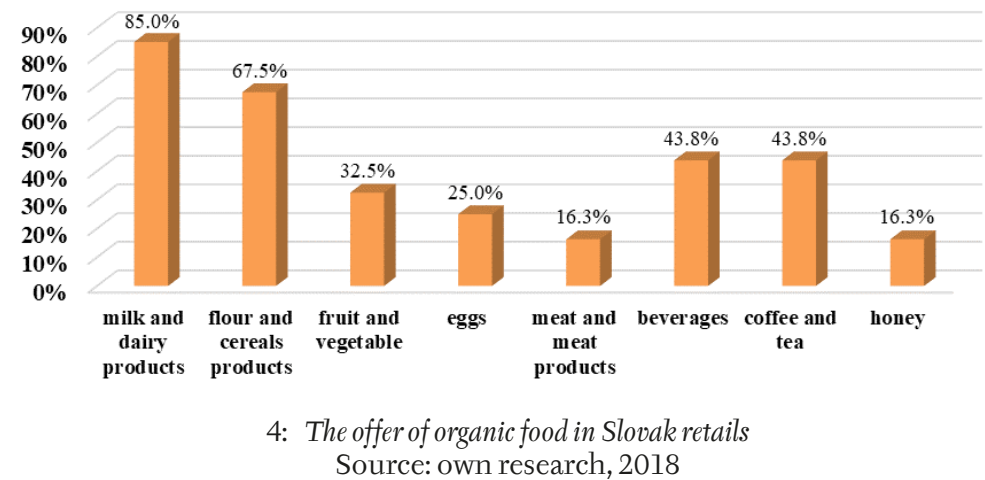


cereal products is offered by $67.5 \%$ of the retails, with Racio, Biomila and Ravita being the most frequent suppliers. $43.7 \%$ of the retails also offer bio drinks, mainly fruit juices, organic tea and coffee from producers Aloe Vera, Biocare, Ovko, Biolinie, M.DER. LLC. 32.5\% of retails offer fruit and vegetable from organic farming, most often ordered from Bonduelle and local eco-farms. Eco-farms and Novogal company deliver organic eggs into $25 \%$ of all interviewed retails. $16.25 \%$ of analysed stores also offer organic meat and meat products as a part their assortments supplied by Hyza, Alfa Bio and Biopark-Farma PD Cvikov, which is mainly oriented on delivering beef. Same percentage of retails also offer the organic honey from Medar company. The supply of individual product categories of organic food, offered in Slovak retails stores, is illustrated in Fig. 4.

All the above-mentioned, fresh food is mainly supplied by Slovak producers, especially in order to preserve freshness, durability and quality of food. In case of durable food, retails may also choose among foreign producers. Based on the research results it could be concluded that more than $90 \%$ of retails managers prefer Slovak food producers if the product category allows it. Moreover, the representation of organic food products of Slovak origin in retails was examined. In $27.5 \%$ of the surveyed retail stores, the share of Slovak organic food is above $75 \%, 13.75 \%$ has a share of organic food with Slovak origin of $50-74 \%$ and $17.50 \%$ offer Slovak organic food in the range of $25-49 \%$. Research found that $18.75 \%$ of the stores offer a very small portion of organic food from Slovak producers.

Existing situation can be determined by individual product categories, where retails that offer more dairy products, meat and pastry prefer Slovak producers and those retails that have a larger range of durable products such as fruit juices, tea, coffee, cereals choose foreign suppliers. The main criteria for their decision could be a lower price compared to Slovak competitors. The presented results and statements are supported by the results of consumer research, which was focused on the importance of criteria considered during purchase of organic food. Fig. 5 shows the importance of criteria as price, quality, origin, producer and brand of the product. Respondents evaluated these criteria on the 5-point scale (1-the most important, 5-the least important). In general, it could be stated, that for Slovak consumers, the most important factor is quality, origin and price, while the less important are producer and brand.

As it was mentioned before, the quality and country of origin are important for Slovak young consumers, however it is necessary to focus on how respondents perceive the price. Regarding this question, the difference in the price perception of organic food between the respondents' genders was examined by applying the Mann-Whitney U test. The calculated the p-value (0.0349) is less than significance level $\alpha=0.05$, which means, that the null hypothesis was rejected and there is a statistically significant difference in price perception between men and women. It could be concluded that women are more price sensitive in comparison to men.

In this context, it needs to be highlighted that the price of products remains a crucial and decisive factor. Of the total number of respondents, up to $71.8 \%$ perceive the price of organic food in Slovakia as high and for this reason this category of food is unavailable to many consumers, as Kubeláková and Košíčiarová (2016) confirmed in their research. The solution would be to extent the sale of organic food under private brands, where a lower price is expected compared to its commercial substitutes. However, the results of retail research showed that only $36.3 \%$ of retails offer organic food under private brands. In general, private brands, such as Tesco Organic, Naše Bio, K-Bio, Coop Jednota Bio and Fresh belong to larger retails chains.

The reason why the consumers do not buy the organic food of Slovak origin on regular basis could be caused by two factors. The first factor is insufficient awareness of consumers about the identification of organic food of Slovak origin and the second factor could be insufficient labelling in the Slovak stores. Consumer research has shown that $42.5 \%$ of respondents are aware of and recognize the identifier of Slovak organic food. $44.0 \%$ of the consumers misidentified the labelling

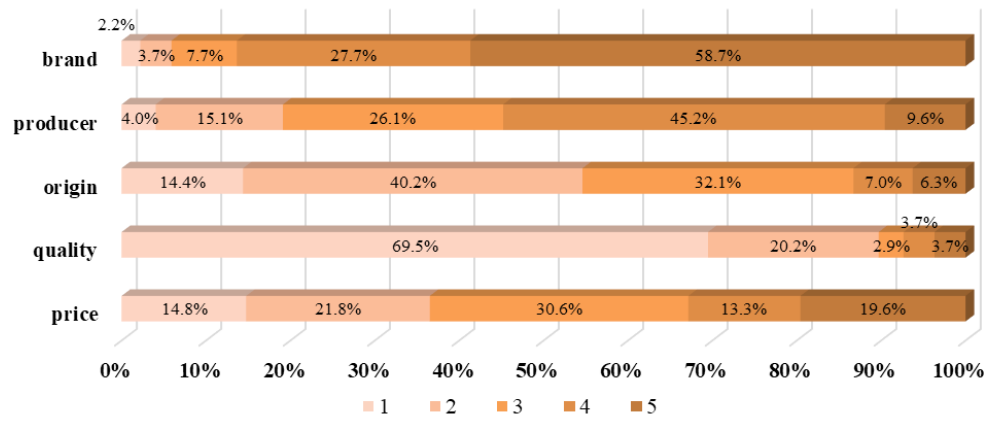

5: The importance of individual organic food selection criteria

Source: own research, 2018 
of Slovak organic food, considering it as an identifier used for organic food produced at European Union level or in Czech Republic. The remaining 13.5\% of consumers do not pay attention to labelling of organic food, and therefore it is assumed that they rely on labels directly in the store's premises. In addition, the survey conducted in retails with managers showed that up to $28.7 \%$ of retails do not have organic food extra labelled and placed among conventional food. Therefore, it could be concluded that if the consumers are not able to identify the organic food by identifier on the product packaging, they might not buy it. $40.0 \%$ of the stores has the organic food placed among the conventional food, but the organic food is visibly and clearly labelled. In this case, the consumer can compare the organic food with a conventional substitute in one place. The results showed that $31.3 \%$ of the stores has a separate place for organic food. This leads to easier and faster consumer orientation in the store. This form is a very good alternative for those consumers who prefer only the purchase of the organic food.

Regarding the food produced in organic farming, it is important to focus on which organic product categories are preferred to buy by consumers. In the context of above mentioned, research was conducted from consumers as well as retailers ' point of view. Based on the results of consumer-targeted survey shown in Fig. 7, it could be stated that most young consumers in the Slovak Republic prefer to buy fruit and vegetable from organic farming (81.1\%), organic milk and dairy products $(40.6 \%)$, meat produced on organic farms (47.7\%), organic eggs (34.9\%) and organic honey (33.5\%). Approximately $24.6 \%$ of the consumers add organic flour and cereal products to their shopping cart, organic coffee and organic tea is preferred by $8.1 \%$ young people and organic drinks are purchased only by $7.7 \%$ of the respondents. In the structure of purchased organic food on the Slovak market according to Kádeková et al. (2017), respondents in different age categories prefer fruit and vegetables (37.0\%), meat and meat products (18.0\%), milk and dairy products (13.0\%), and the least bought category of organic foods are sweets and pastry.

In the context of organic honey, research additionally focused on consumer perception towards this specific product. According to legislation of the European Union, organic honey is produced under strict conditions involving ecological treatment, hives build from natural materials, clean environment without factories, intensive agriculture, air pollution and feeding only with honey. (Council Regulation (EC) No 834/2007; Commission Regulation (EC) No 889/2008). All these aspects are reflected in higher quality of product, however, consumers are not aware and fully informed (Cosmina et al., 2016) and many consumers consider conventional honey from local beekeeper as organic. The last formulated hypothesis examines whether awareness of organic honey influence consumer perception. Based on the results of Fisher 's exact test ( $p$ value $=<.0001$ ), the dependence was proven at significance level $\alpha=0.05$. According to Fig.8, the majority of consumers who know organic honey perceive difference between conventional honey and honey from organic beekeeping.

The results of retail research showed, that the most demanded organic food by retailers' point of view are organic milk, followed by products from cereals and organic flour, fruit and vegetable, eggs, meat and meat products, beverages, organic honey and the least demanded products are tea and coffee. Managers in retails were asked to order the product categories of the organic food according to the customer demand, 1 represents the most demanded organic food and 8 the least demanded. Results showed that the most demanded products according to their average order value were as follows: milk and dairy products (2.07), flour and flour products (2.86), fruit and vegetables (3.08), eggs (3.7), beverages (5.11), honey (5.26), coffee and tea (5.58).

Fig. 9 compares the demand for organic food with supply of organic food according to retailers. The observed differences are the basis for a deeper analysis of the comparison of supply and demand for organic food on Slovak market and the determination of excessive demand or supply in the selected categories of organic food.

Based on the comparison of the demanded and supplied organic food products, it could be concluded that the supply is sufficient in most categories of organic food. In the case of fruit and vegetable, eggs and meat, consumers would welcome a wider offer. Furthermore, research examined whether the stores consider to extent their assortment in the future and based on the results it could be stated that $67.5 \%$ of the surveyed stores consider to extent it. $28.75 \%$ of stores would expand the section of fruit and vegetables from organic farming, same percentage of retails would extend their assortment by organic eggs. It could be assumed that if these categories will be added, the current supply will cover the demand in case of organic food on the Slovak market. Živělová and Crhová (2013) suggest that the demand for organic food will gradually increase which will create space for organic farmers, processors, distributors and sellers of organic food.

Nevertheless, the attention should be paid to consumers who do not buy organic food. Based on the results obtained, it could be stated that currently $58.18 \%$ of the young consumers do not prefer to consume the given food category. The main barrier of consumption for $29.56 \%$ respondents is economic factor connected with higher prices. Other reasons were mistrust in the quality of food (25.19\%) and lack of information about the reasons for buying (17.22\%). The same barriers of purchase were identified by Kubeláková and Košičiarová (2016), Savov et al. (2011) and Ham et al. (2016). Based on these factors, it is appropriate to spread 

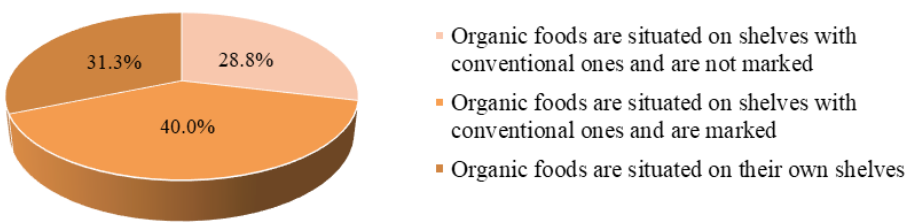

- Organic foods are situated on their own shelves

6: Merchandising of organic food in the Slovak retail store Source: own research, 2018

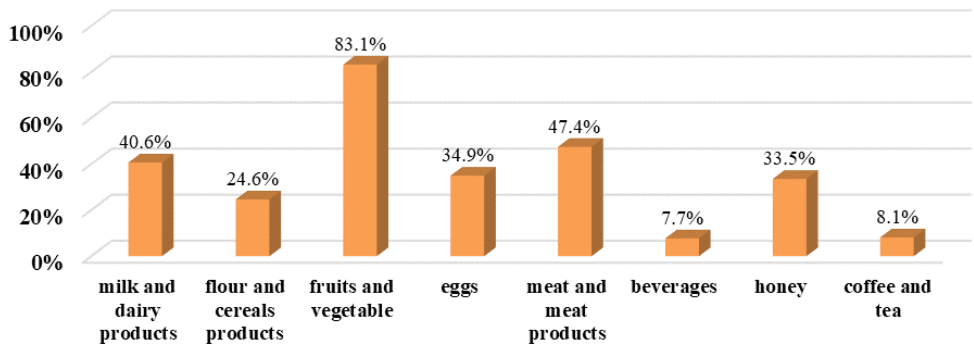

7: The most demanded categories of organic food from the consumers' point of view Source: own research, 2018

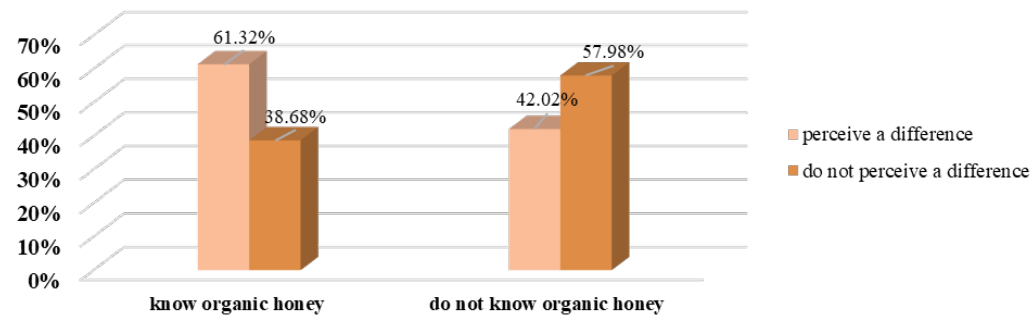

8: Consumerperception towards organic honey Source: own research, 2018

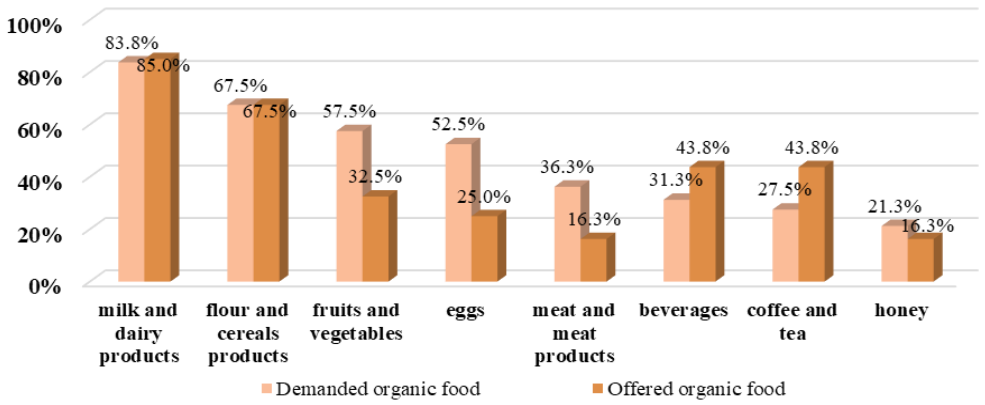

9: The most demanded organic product categories in comparison to the most offered organic food (\% of retails, which marked particular categories of organic food as demanded from 1-4 and \% of retails, which offer these categories of organic food) Source: own research, 2018

the information and educate the consumers about the reasons for purchase food produced in organic farming and to emphasize the quality, health aspect and method of processing which is friendlier to the environment (Kozelová et al., 2013; Bryla, 2016). Mentioned factors are also confirmed by the Slovak young consumers purchasing organic food. They consume organic food for their positive health impact $(36.76 \%)$ and due to their higher quality
(25.74\%) in comparison with the conventional ones. Information should be communicated to young consumers by social media because of young people use social media as a source of information and they are influenced by it. This statement is also proved by results of the questionnaire research, which suggests, that $46.22 \%$ of respondents consider social networks as the most suitable tool for searching and promoting organic food. 


\section{CONCLUSION}

Food market is characterised by constant changes which are determined by consumers' behaviour. Increasing interest in purchase of organic products could by consider for the current trend in food market. The aim of the paper was to analyse the current situation on market with food produced in organic farming. Research included questionnaire survey in Slovak retail stores and questionnaire survey focused on consumer behaviour of young generation in Slovakia. Based on the results, it could be concluded that nowadays organic food is offered in $75.0 \%$ of surveyed retail stores. Consumers living in villages prefer to purchase organic food in supermarkets and hypermarkets while those who are living in the city prefer specialized shops. Slovak retail stores offer relatively wide range of organic food such as fruits and vegetables, milk and dairy products, meat products, mill products, beverages, eggs, honey, coffee and tea. Consumers mostly prefer to buy fruits and vegetables, meat and dairy products. Approximately $41.0 \%$ of respondents purchase organic food and in future it is expected increase in consumption of this category due to its higher quality and health aspect. Retail stores consider to extend their organic assortments by adding fruits and vegetables, meat products and eggs. At purchase of organic products, consumers consider as the most important the quality, country of origin and price. In terms of price, young women are more price-sensitive than young men. Furthermore, study examined the barriers for purchasing organic food and the most frequent were higher prices and insufficient information. Young consumers should be educated and more informed about reasons why to consume organic food by using predominantly internet and social media due to the fact that $46.22 \%$ of respondents use internet for searching information.

\section{REFERENCES}

AERTSENS, J., MONDELAERS, K., VERBEKE, W. et al. 2011. The influence of subjective and objective knowledge on attitude, motivations and consumptions of organic food. British Food Journal, 113(11): 1353-1378.

BRYLA, P. 2016. Organic food consumption in Poland: Motives and barriers. Appetite, 105(1): 737-746

CENTRAL INSTITUTE OF CONTROL AND TESTING IN BRATISLAVA. 2018. Datasets. ÚKSÚP. [Online]. Available at: http://www.uksup.sk/ozpep-datasety/ [Accessed: 2018, January 31].

CHRYSOCHOU, P. 2010. Food health branding: The role of marketing mix elements and public discourse. Journal of Marketing Communications, 16(1-2): 69-85.

COSMINA, M., GALLENTI, G., MARAGON, F. et al. 2016. Attitudes towards honey among Italian consumers: A choice experiment approach. Appetite, 99: 52-58.

DEMERITT, L. 2002. All Things Organic 2002: A Look at the Organic Consumer. Washington, Bellevue: The Hartman Group.

EUROPEAN UNION. 2007. Council Regulation (EC) No 834/2007 of 28 June 2007 on organic production and labelling of organic products and repealing Regulation (EEC) No 2092/91. In: Official Journal of European Union. [Online]. Available at: http://eur-lex.europa.eu/LexUriServ/LexUriServ.do?uri=OJ\%3AL\%3A2007 \%3A189\%3A0001\%3A0023\%3AEN\%3APDF [Accessed: 2018, October 15].

FRÝDLOVÁ, M. and VOSTRÁ, H. 2011. Determinants influencing consumer behaviour in organic food market. Acta Universitatis Agriculturae et Silviculturae Mendelianae Brunensis, 59(7): 111-120.

GOTTSCHALK, I. and LEISTNER, T. 2013. Consumer reactions to the availability of organic food in discount supermarkets. International Journal of Consumer Studies, 37(2): 136-142.

HAM, M., PAP, A. and BILANDZIC, K. 2016. Perceived barriers for buying organic food products. In: Economic and Social Development: Book of Proceedings of 18th International Scientific Conference on Economic and Social Development-"Building Resilient Society". Zagreb, 9-10 December. Varazdin: Varazdin Development and Entrepreneurship Agency, pp. 162-174.

HUGHNER, R. S., MCDONATH, P., PROTHERO, A. et al. 2007. Who are organic food consumers? A compilation and review of why people purchase organic food. Journal Consumer Behaviour, 6(2-3): 94-110.

KÁDEKOVÁ, Z., RÉCKY, R., NAGYOVĀ, L'. et al. 2017. Consumer's purchasing preferences towards organic food in Slovakia. Potravinárstvo, 11: 731-738.

KALUŽÁKOVÁ, H. 2011. Biopotraviny a slovenskí spotrebitelia: Organic products and Slovak consumers. In: Podnikanie na vidieku (obchodnéprávo EÚ I). Pol'ný Kesov, 12-13 May. Nitra: Slovak University of Agriculture in Nitra, pp. 134-139.

KOŠIČIAROVÁ, I., NAGYOVÁ, L'. and HOLIENČINOVÁ, M. 2017. Consumer Behaviour on Slovak Yoghurt and Fermented Milk Products Market. Acta Universitatis Agriculturae et Silviculturae Mendelianae Brunensis, 65(6): 1967-1978.

KOZELOVÁ, D., FIKSELOVÁ, M., VIETORIS, V., and CZAKO, P. 2013. Analysis of the Slovak consumer behaviour regarding the organic food purchase. Acta Universitatis Agriculturae et Silviculturae Mendelianae Brunensis, 61(7): 2343-2350 
KRETTER,A.2005. Marketing ekologického polnohospodárstva a ekoproduktov. Nitra:Slovenská pol'nohospodárska univerzita v Nitre.

KRETTER, A. and KÁDEKOVÁ, Z. 2013. Eco marketing in agriculture and barriers to organic food sales. Zeszyty Naukowe Szkoły Głównej Gospodarstwa Wiejskiego w Warszawie, 59(10): 394-401.

KUBELAKOVÁ, A. and KOŠIČIAROVÁ, I. 2016. Organic food and its position in retail stores in Slovak Republic. In: The agri-food value chain: challenges for natural resources management and society. Slovak University of Agriculture in Nitra, 19 - 20 May. Nitra: Slovak University of Agriculture in Nitra, 1036-1042.

LEHMANN, M. 2005. The organic food market [In German: Der Biomarktbehauptetsich]. Bio Aktuell, 3: 22-23.

MAGNUSSON, M.K., ARVOLA, A., HURSTI, U.K. K. et al. 2003. Choice of organic foods is related to perceived consequences for human health and to environmentally friendly behaviour. Appetite, 40(2): 109-117.

NAGYOVÁ, L. et al. 2012. Present and starting points for the sale of agro-food products in the retail chains of the Slovak Republic [in Slovak: Súčasnost'a východiská predaja agropotravinárskych produktov v maloobchodných ret'azcoch SR]. Nitra: Slovenská pol'nohospodárska univerzita v Nitre.

NAGYOVÁ, L., HORSKÁ, E., PALUCHOVÁ, J. et al. 2012. Trends in consumer behaviour on the food products market in the Slovak Republic [in Slovak: Trendy v spotrebitel'skom správani na trhu potravinárskych produktov v SR]. Nitra: Slovenská pol'nohospodárska univerzita v Nitre.

PALUCHOVÁ, J. and BENDA PROKEINOVÁ, R. 2014. Creation of responsible behavior and impact on sustainable customer buying behavior in retail sector. Visegrad journal on bioeconomy and sustainable development, 3(1): 39-45.

PREDANOCYOVÁ, K., ŠEDÍK, P., KUBICOVÁ, L. et al. 2017. Consumer perception towards organic food in Slovakia. In: Innovation as a driving force of sustainable development. Szent István University in Gödöllö, 22 November. Gödöllö: SzentIstván University, pp. 299-314.

RESEARCH INSTITUTE OF AGRICULTURAL AND FOOD ECONOMICS. 2018. Zelená správa 2016. [Online]. Available at: http://www.vuepp.sk/dokumenty/zelena/zelena2016.pdf [Accessed: 2018, February 5].

ROVNÝ, P., APPEL, F., BALMANN, A. et al.2010. Food chain management - European experiences and local solutions. Graz: Mail Boxes Etc.

SAVOV, R., LANČARIČ, D., KOZÁKOVÁ, J. et al. 2011. Actual problems of organic farming in Slovakia [In Slovak: Súčasné problémy ekologického polnohospodárstva na Slovensku]. Actaoeconomica et informatica: vedeckýčasopis pre ekonomiku a informatiku v pol'nohospodárstve, 14(2): 53-57.

VÁCLAVÍK, T. 2009. Czech organic food market 2009: In addition: The Slovak organic food market [In Czech: Česky trh s biopotravinami 2009: Navíc: Slovenský trh s biopotravinami]. Praha: České a slovenské odborné nakladeteství.

WITEK, L. 2016. Influence of Socio-demographic Characteristics of Consumers on Attitudes Towards Cause Related Marketing. Acta Universitatis Agriculturae et Silviculturae Mendelianae Brunensis, 64(6): 2173-2182.

YIRIDOE, E. K., BONTI-ANKOMAH, S. and MARTIN, R. C. 2005. Comparison of consumer perceptions and preference toward organic versus conventionally produced foods: A review and update of the literature. Renewable Agriculture Food System, 20(4): 193-205.

ZÁMKOVÁ, M. and PROKOP, M. 2013. Consumers behaviour of students when shopping for organic food in the Czech Republic. Acta Universitatis Agriculturae et Silviculturae Mendelianae Brunensis, 61(4): 1191-1201.

ZÁMKOVÁ, M. and PROKOP, M. 2014. Comparison of Consumer Behavior of Slovaks and Czechs in the Market of Organic Products by Using Correspondence Analysis. Acta Universitatis Agriculturae et Silviculturae Mendelianae Brunensis, 62(4): 783-795.

ŽIVĚLOVÁ, I. and CRHOVÁ, M. 2013. Organic food market in the Czech Republic. Acta Universitatis Agriculturae et Silviculturae Mendelianae Brunensis, 61(2): 539-546.

Kristína Predanocyová: kristina.predanocyova@gmail.com

Peter Šedík: sedik.peter@gmail.com

Lubica Kubicová: kubicova.lubka@gmail.com

Elena Horská: elena.horska@gmail.com 